Studia nad Autorytaryzmem i Totalitaryzmem 43, nr 3

Wrocław 2021

https://doi.org/10.19195/2300-7249.43.3.5

KAROL KICZKA

ORCID: 0000-0002-3056-024X

Uniwersytet Wrocławski

karol.kiczka@uwr.edu.pl

\title{
Sądowoadministracyjna kontrola przyjęć na studia w PRL
}

\author{
Slowa kluczowe: prawo administracyjne, przyjęcia na studia, państwo autorytarne, Polska \\ Rzeczpospolita Ludowa (PRL).

\section{JUDICIAL-ADMINISTRATIVE REVIEW OF COLLEGE ADMISSION DECISIONS IN THE POLISH PEOPLE'S REPUBLIC}

\begin{abstract}
The scope of judicial review regarding the application of administrative law in the authoritarian Polish People's Republic (Polska Rzeczpospolita Ludowa - PRL) was limited. The reason for this is obvious: resolving disputes between executive power (public administration) and individuals in PRL by courts functioning in honest and effective way would be an "obstruction" of the tasks executed by the communist state. The Supreme Administrative Court was reactivated in the last stage of PRL's functioning in 1980, following the model of interwar tradition. The paper offers an analysis of judicial-administrative review in PRL in the field of university admissions.

Organization and functioning of the authoritarian PRL exerted an influence on the way judicial review of public administration operated. Administrative justice reactivated in 1980 was submitted to organizational and jurisdictional limitations, as the created Supreme Administrative Court was a one-instance institution with limited jurisdiction, filled with only nine judges. Still, reactivating administrative justice began the process of restoring the proper place for freedoms and individual rights against the state, including the right to attend higher education schools.

The analysis of the chosen case has allowed to identify some significant interconnected processes and phenomena in the judicial-administrative review in the declining stage of PRL within the whole domain of administrative law. One example is public administration striving for avoiding judicial review by taking a position that settlement of an administrative matter by the university is not an administrative decision. Another example is regulation of individual freedoms and rights by a multi-layered unstable system of legal sources, including: law on higher education, or-
\end{abstract}


der of the Minister for Science, Higher Education and Technology, and non-published guidelines from the Minister of Health and Social Welfare of 21 May 1981 on admission principles and procedure of full-time studies at medical universities.

Keywords: administrative law, admission procedure, authoritarian state, Polish People's Republic (Polska Rzeczpospolita Ludowa - PRL).

\section{Wprowadzenie}

W odróżnieniu od państw autorytarnych czy totalitarnych rzetelna sądowa kontrola działalności administracji publicznej, podobnie jak i innych składowych władzy publicznej, należy do kanonów demokratycznego państwa prawnego. Autorytaryzm i totalitaryzm, jak pisze G. Sartori, to nowe twory językowe, które pojawiły się w przededniu pierwszej wojny światowej. Kiedy więc pada dziś pytanie: co jest przeciwieństwem demokracji?, zwykle, w opinii tegoż autora, odpowiadamy totalitaryzm albo autorytaryzm. Przyjmuje się zazwyczaj, że to właśnie totalitaryzm stanowi najpełniejsze zanegowanie demokracji ${ }^{1}$. Niebezpieczeństwo polega na tym, zdaniem H. Arendt, że globalna, uniwersalnie powiązana cywilizacja może wytworzyć barbarzyńców z samej siebie, zmuszając miliony ludzi do życia w warunkach, które wbrew wszelkim pozorom są warunkami życia dzikach ${ }^{2}$.

Od czasów Monteskiusza, jak podkreśla C. Znamierowski, wysuwany jest postulat kontroli zewnętrznej, którą nad działaniem jednej władzy publicznej ma wykonywać inna władza publiczna. Myśl ta urzeczywistniona jest w znacznej mierze we współczesnym ustroju państwowym. Sądownictwo kontroluje legislatywę, o ile bada zgodność ustaw z konstytucją; administrację publiczną zaś, jeśli orzekać może o legalności jej działań. Działania normodawcze ciała zbiorowego (parlamentu), z którego z czasem zniknąć może postać jednoosobowego władcy, mogą być tak nieograniczone żadną normą jak działania despoty. Parlament może być — w opinii Znamierowskiego — władcą despotycznym i równie niebezpiecznie wszechwładnym jak jednostka. Normodawca parlamentarny może zagrażać bezpieczeństwu prawnemu nie mniej niż monarcha nieograniczony ${ }^{3}$.

W okresie Polskiej Rzeczypospolitej Ludowej ${ }^{4}$, która została zniesiona na mocy ustawy z dnia 29 grudnia 1989 roku o zmianie Konstytucji Polskiej Rzeczypospolitej Ludowej ${ }^{5}$, mimo postulatów między innymi piśmiennictwa sądowa

1 G. Sartori, Teoria demokracji, przeł. P. Amsterdamski, D. Grinberg, Warszawa 1994, s. 232.

${ }^{2}$ H. Arendt, Korzenie totalitaryzmu, t. 1, przeł. D. Grinberg, M. Szawiel, Warszawa 1989, s. 234

3 C. Znamierowski, Elita, ustrój, demokracja. Pisma wybrane, Warszawa 2001, s. 115.

4 Konstytucja Polskiej Rzeczypospolitej Ludowej uchwalona przez Sejm Ustawodawczy w dniu 22 lipca 1952 r., tekst jedn. Dz.U. z 1976 r. Nr 7, poz. 36 (dalej: Konstytucja PRL).

5 Art. 1 ustawy z dnia 29 grudnia 1989 r. o zmianie Konstytucji Polskiej Rzeczypospolitej Ludowej, Dz.U. Nr 75, poz. 444. 
kontrola administracji publicznej miała charakter marginalny ${ }^{6}$. W ostatnim okresie państwa autorytarnego - Polskiej Rzeczypospolitej Ludowej na podstawie ustawy z dnia 31 stycznia 1980 roku o Naczelnym Sądzie Administracyjnym oraz o zmianie ustawy - Kodeks postępowania administracyjnego ${ }^{7}$ reaktywowano wzorem naszej międzywojennej tradycji sądownictwo administracyjne. Niemniej, jak podkreśla J. Trzciński: narzucając jednak przywróconemu sądownictwu administracyjnemu bardzo wiele ograniczeń organizacyjnych i kompetencyjnych, początkowo w jednoinstancyjnym i o organicznej kognacji Naczelnym Sądzie Administracyjnym było dziewięciu sędziów ${ }^{8}$. Ogólnie rzecz ujmując, organizacja i funkcjonowanie Polskiej Rzeczypospolitej Ludowej wkomponowywało się także w zakresie sądowej kontroli administracji publicznej w charakterystyczne znamiona państwa autorytarnego 9 .

Celem niniejszego opracowania jest analiza określonych aspektów wybranego przejawu kontroli sądowoadministracyjnej z obszaru prawa administracyjnego — szkolnictwa wyższego w zakresie przyjęć na studia w PRL ${ }^{10}$. Rozważany dalej judykat był też przedmiotem zainteresowania prasy codziennej. Aleksander S. zdał na studia lekarskie. Nie został jednak przyjęty, ponieważ zabrakło mu punktów preferencyjnych za pracę w służbie zdrowia. Paradoks tej sprawy, jak zauważa Ż. Semprich, polegał na tym, że Aleksander S. faktycznie pracował przy chorych, lecz nie pobierał wynagrodzenia. W miejscu zatrudnienia dostawał tylko

${ }^{6}$ Zob. J. Litwin, Problematyka sq̨downictwa administracyjnego. Zagadnienia organizacji i procedury, „Nowe Prawo” 1956, z. 10, s. 6-9; T. Bigo, Trzy sugestie w sprawie sadownictwa administracyjnego, „Zeszyty Naukowe Uniwersytetu Wrocławskiego” 1958, Seria A, nr 10, „Prawo” 3, s. 13-14; J. Świątkiewicz, Sadowa kontrola działalności administracji w PRL, „Państwo i Prawo” 1976, nr 8-9, s. 32-41; M. Wyrzykowski, Sądownictwo administracyjne w Polskiej Rzeczpospolitej Ludowej, Warszawa 1983.

7 Ustawa z dnia 31 stycznia 1980 r. o Naczelnym Sądzie Administracyjnym oraz o zmianie ustawy — Kodeks postępowania administracyjnego, Dz.U. Nr 4, poz. 8 (dalej: NSA).

8 J. Trzciński, Sądownictwo administracyjne jako gwarant ochrony wolności i praw jednostki, [w:] Trzecia władza. Sąy i trybunały w Polsce. Materiały z L Ogólnopolskiego Zjazdu Katedr i Zaktadów Prawa Konstytucyjnego, Gdynia 24-26 kwietnia 2008 roku, red. A. Szmyt, Gdańsk 2008, s. 129.

9 Por. G. Sartori, op. cit., s. 232-238; Ch. Gati, Wprowadzenie, [w:] Zbigniew Brzeziński. Strateg i maż stanu, red. Ch. Gati, Warszawa 2014, s. 18; G.F. Kennan, Totalitaryzm w świecie współczesnym, [w:] Totalitaryzm. Materiały z konferencji zorganizowanej przez Amerykańska Akademię Sztuk i Nauk w marcu 1953 roku, red. C.J. Friedrich, przeł. S. Szymański, Warszawa 2019, s. 47; R. Bäcker, J. Rak, Polski autorytaryzm 2015-2019, [w:] W kręgu doktryn politycznych i prawnych. Ksiega jubileuszowa dedykowana Profesorowi Markowi Maciejewskiemu, red. R. Antonow et al., Wrocław 2020, s. 75.

10 Wyrok Naczelnego Sądu Administracyjnego z dnia 29 czerwca 1982 r., II SA 532/82. Centralna Baza Orzeczeń Sądów Administracyjnych (CBOSA), (dalej: wyrok, orzeczenie). Por. J. Homplewicz, Glosa, Orzecznictwo Sądów Polskich i Komisji Arbitrażowych 1983, z. 1, poz. 20, s. 53-56; J. Filipek, Glosa, „Państwo i Prawo” 1983, nr 8, s. 148-151; J. Ciechocki, Komentarz, „Organizacja Metody Techniki” 1984, nr 3, s. 42-46. 
wyżywienie ${ }^{11}$. W związku z tym wykorzystany zostanie głównie wybrany materiał źródłowy z praktyki oraz poglądy piśmiennictwa dotyczący omawianych kwestii.

\section{O sądowej kontroli administracji publicznej i szkolnictwie wyższym w państwie}

W uniwersyteckim wykładzie na temat roli kontroli w porządku prawnym właściwym władzy wykonawczej T. Bigo zauważa, że kontrola administracji jest to system środków i urządzeń zmierzających do zapewnienia prawidłowości administracji publicznej ${ }^{12}$. Dlatego ważną część składową każdej konstytucji — jak podkreślał w II Rzeczypospolitej J.S. Langrod — stanowić muszą podstawowe przepisy o sądownictwie administracyjnym ze względu na jego wręcz wyjątkową, choć nie zawsze docenianą wagę dla ustroju współczesnego i przyszłego państwa. Chodzi tu o kontrolę nad dziedziną życia publicznego (władzą wykonawczą), która wskutek - w opinii autora - tradycji państwa absolutnego, w wyniku nieodporności wobec wpływów politycznych i ogromu agend jej przekazanych, jest szczególnie podatna na krzewienie się najszerzej pojętego bezprawia. Bezprawie to szczególnie szkodzi rozumnie pojętym interesom zbiorowym i indywidualnym ${ }^{13}$. Na kanwie kształtowania się systemów administracji publicznej w poszczególnych formacjach państwowych M. Zimmermann trafnie stwierdził, że sądownictwo administracyjne jest ostatnią i najważniejszą gwarancją systemu „państwa praworządnego" ${ }^{14}$. Fundamentalna różnica między administracją publiczną a sądownictwem, jak pisze F. Longchamps na kartach pracy habilitacyjnej wyeliminowanej $\mathrm{z}$ oficjalnego obiegu naukowego przez władze autorytarnego polskiego państwa, leży w różnicy postawy urzędnika administracyjnego i sędziego: urzędnik służył monarsze, sędzia społeczeństwu; urzędnik państwu, sędzia prawu ${ }^{15}$.

Współcześnie orzecznictwo trybunalskie uwypukla, że rzetelność i sprawność działania instytucji publicznych, w szczególności zaś tych instytucji, które zostały stworzone $\mathrm{w}$ celu realizacji i ochrony praw gwarantowanych przez Konstytucję, należy do wartości mających rangę konstytucyjną ${ }^{16}$. Wynika to

11 Ż. Semprich, Spór o indeks, „Rzeczpospolita” 24.08.1983, s. 6.

12 T. Bigo, Prawo administracyjne, cz. 1. Instytucje ogólne, Wrocław 1948, s. 204.

13 J.S. Langrod, Kontrola administracji. Studja, Warszawa 1929, s. 13. Zob. B. Adamiak, Instytucje prawne równowagi władzy wykonawczej $i$ władzy sądowniczej $w$ procesowym prawie administracyjnym i sadowoadministracyjnym, [w:] W kręgu doktryn politycznych i prawnych, s. 13.

14 M. Zimmermann, Nauka administracji i polskie prawo administracyjne. Część I, Poznań 1949, s. 24.

15 F. Longchamps, Założenia nauki administracji, Wrocław 1949, s. 196. Zob. Pismo Ministerstwa Szkół Wyższych i Nauki z dnia 26 stycznia 1951 r. Nr DN-55/pfu/50.r. POUFNE.

16 Konstytucja Rzeczypospolitej Polskiej z dnia 2 kwietnia 1997 r., Dz.U. Nr 78, poz. 483, sprost. Dz.U. z 2001 r. Nr 28, poz. 319 z późn. zm. (dalej: Konstytucja RP, Konstytucja). 
jasno z tekstu wstępu do Konstytucji (preambuły Konstytucji), w którym jako dwa główne cele ustanowienia Konstytucji wymieniono: zagwarantowanie praw obywatelskich oraz zapewnienie rzetelności i sprawności działania instytucji publicznych. Przepisy, których treść nie sprzyja rzetelności lub sprawności działania instytucji mających służyć ochronie praw konstytucyjnych, są zarazem naruszeniem tych praw, a tym samym uzasadnione jest ich uznanie za niezgodne z Konstytucją. Znaczenie zasady rzetelności i sprawności działania - w odniesieniu do sądów - według Trybunału Konstytucyjnego wyraża się zwłaszcza w tym, że ustrój wymiaru sprawiedliwości (sądów) realizować ma, najogólniej rzecz biorąc, dwie najważniejsze wytyczne konstytucyjne, a mianowicie zapewniać sądom jako instytucjom publicznym rzetelność i sprawność. Regulacja ustroju sądów ma służebne znaczenie wobec przysługującego każdemu prawa do rozpatrzenia jego sprawy w sposób sprawiedliwy, jawny i bez nieuzasadnionej zwłoki przez właściwy, niezależny, bezstronny i niezawisły sąd (art. 45 ust. 1 Konstytucji). Rzetelność działania sądów oznacza w tym kontekście przede wszystkim ich bezstronność, niezależność i niezawisłość, sprawność zaś - eliminację w miarę możliwości przedłużania się postępowania sądowego ponad uzasadnioną konieczność. Przy czym środki prawne służące zapewnieniu sprawności wymiaru sprawiedliwości nie mogą jednak naruszać podstawowych gwarancji niezawisłości i bezstronności sędziego oraz ingerować w sprawowanie wymiaru sprawiedliwości. Sprawność postępowania nie może być uważana za wartość uzasadniającą ingerencję w niezawisłość sędziów ${ }^{17}$.

Doniosłe znaczenie stosunków społecznych właściwych obszarowi kształcenia (edukacji, nauczania, oświaty itp.) powoduje, że od dawna przynależą do domeny prawa, w tym głównie prawa administracyjnego ${ }^{18}$. Na poparcie wskażmy na przykład rozważania J. Buzka w przedmiocie obowiązku szkolnego i przymusu szkolnego ${ }^{19}$. Odnośny obszar ma fundamentalne znaczenie dla przestrzeni publicznej i prywatnej. $Z$ bardzo licznych tego przykładów zaakcentujmy za J. Buzkiem tylko jeden, wyjęty z tomu czwartego urzędowej publikacji rosyjskiej pod tytułem: Istoriczeskij obzor diejatielnosti komiteta ministrow. Petersburg w roku 1902. W raporcie swym za lata 1889-1893 zaznaczył, jak pisze autor, jenerał gubernator kijowski, że ,z pomocą samej szkoły cerkiewnej nie można walczyć z łacińsko-polską propagandą i z tendencyą odosobniania się u żydów i niemców. W interesie dzieła obruszczenia jest ważną rzeczą, ażeby szkoły ludowe utrzymywał skarb państwa, ażeby je uczynić niezawisłemi od gmin

17 Wyrok Trybunału Konstytucyjnego z dnia 9 marca 2016 r., K 47/15, Orzecznictwo Trybunału Konstytucyjnego. Zbiór Urzędowy 2016. Seria A, poz. 2, s. 85.

18 Por. K.W. Kumaniecki, J.S. Langrod, S. Wacholz, Zarys ustroju, postepowania i prawa administracyjnego w Polsce, Kraków 1939; M. Jaroszyński, M. Zimmermann, W. Brzeziński, Polskie prawo administracyjne, Warszawa 1956.

19 J. Buzek, Studya z zakresu administracyi wychowania publicznego. I. Szkolnictwo ludowe, Lwów 1904. 
wiejskich”. Uwypuklane zdanie spowodowało dopisek Aleksandra III „słusznie”, a stało się w dalszym ciągu w prowincjach zabranych przyczyną zakładania szkół ludowych wyłącznie na koszt państwa ${ }^{20}$.

Zadania publiczne w obszarze szkolnictwa wyższego były przedmiotem wypowiedzi zwłaszcza K. Twardowskiego ${ }^{21}$. Uniwersytet w opinii autora

powołany jest do służenia prawdzie naukowej, wiedzy objektywnej, oraz do doskonalenia metod badania, przedewszystkiem uczyć winien myślenia naukowego jako tego właśnie sposobu myślenia, który do owej wiedzy i prawdy prowadzi. Możność spełniania właściwych Uniwersytetowi zadań jest uwarunkowana jego - jak określa autor — bezwzględną duchową niezależnością. Duchową — bo materialnie Uniwersytet, o ile nie stoi o własnych siłach, będzie zawsze zależny od tego czynnika, który mu daje finansowe podstawy istnienia i wyposaża go w środki do pracy. Ale ci, co Uniwersytety fundują i utrzymują, dowiedliby zupełnego niezrozumienia istoty Uniwersytetu, gdyby chcieli w czemkolwiek krępować jego pracę, z góry zastrzegać się przeciw pewnym jej wynikom, wskazywać, jakie rezultaty byłyby pożądane. I gdyby nawet wyniki pracy naukowej Uniwersytetu były niemiłe tym, którym on zawdzięcza swój byt nie wolnoby w tem upatrywać uprawnienia do nakładania mu jakichkolwiek więzów, do stosowania jakichkolwiek ograniczeń ${ }^{22}$.

Szkolnictwo wyższe i nauka, normowane aktualnie Prawem o szkolnictwie wyższym i nauce ${ }^{23}$, uprzednio Prawem o szkolnictwie wyższym ${ }^{24}$, oraz inne właściwe w tym zakresie regulacje prawne mają charakter wykonawczy w stosunku do wypowiedzi jurydycznych ulokowanych w Konstytucji ${ }^{25}$. Ustrojodawca w szczególności przyjmuje, że każdy ma prawo do nauki. Nauka w szkołach publicznych jest bezpłatna. Ustawa może dopuścić świadczenie niektórych usług edukacyjnych przez publiczne szkoły wyższe za odpłatnością. Rodzice mają wolność wyboru dla swoich dzieci szkół innych niż publiczne. Obywatele i instytucje mają prawo zakładania szkół podstawowych, ponadpodstawowych i wyższych oraz zakładów wychowawczych. Warunki zakładania i działalności szkół niepublicznych oraz udziału władz publicznych $w$ ich finansowaniu, a także zasady nadzoru pedagogicznego nad szkołami i zakładami wychowawczymi, określa ustawa. Władze publiczne zapewniają obywatelom powszechny i równy dostęp do wykształcenia. W tym celu tworzą i wspierają systemy indywidualnej pomocy finansowej i organizacyjnej dla uczniów i studentów. Zapewnia się autonomię szkół wyższych na zasadach określonych w ustawie (art. 70 Konstytucji). Orzecznictwo sądowe uwypukla, że oświatę oraz kształcenie należy zaliczyć do zadań

20 Ibidem, s. 302.

${ }^{21}$ K. Twardowski, O dostojeństwie Uniwersytetu, Poznań 2011 (reprint wyd. z 1933 r.), pkt 5-7.

22 Ibidem.

${ }^{23}$ Ustawa z dnia 20 lipca 2018 r. — Prawo o szkolnictwie wyższym i nauce, Dz.U. z 2020 r. poz. $85 \mathrm{z}$ późn. zm.

${ }^{24}$ Ustawa z dnia 27 lipca 2005 r. — Prawo o szkolnictwie wyższym, Dz.U. z 2012 r. poz. 57 z późn. zm.

25 Por. J. Boć, Konstytucja a prawo administracyjne, „Ruch Prawniczy, Ekonomiczny i Socjologiczny" 2011, z. 2, s. 70. 
publicznych nawet wtedy, gdy są one wykonywane przez szkoły niepubliczne. Podmioty reprezentujące szkoły niepubliczne o uprawnieniach szkoły publicznej są obowiązane do udostępniania informacji publicznych w zakresie dotyczącym wykonywania przez te szkoły zadań publicznych ${ }^{26}$.

\section{Causa - sprawa przyjęcia na studia w okresie PRL}

Wspomniany we wprowadzeniu Aleksander S. został dopuszczony do studiowania - nie otrzymał jednak żadnych dokumentów stwierdzających, że jest studentem. Choć, jak pisze Ż. Semprich, pracowicie uczęszczał na zajęcia dla pierwszego roku studiów lekarskich i z powodzeniem zdawał pierwsze egzaminy — rektor nie pozwolił mu zaliczyć całej sesji. Miała to być kara za to, że się ośmielił zaskarżyć do Naczelnego Sadu Administracyjnego działania uczelni i ministra $\mathrm{w}$ sprawie przyjęcia na studia. Ponadto w świetle obowiązujących w PRL przepisów prawa zawisł nad Aleksandrem S. obowiązek służby wojskowej i sankcje z ustawy o uchylaniu się od pracy ${ }^{27}$.

Konstytucja PRL (art. 72) stanowiła w interesującym nas temacie, że obywatele Polskiej Rzeczypospolitej Ludowej mają prawo do nauki. Prawo do nauki zapewniają w coraz szerszym zakresie:

1. bezpłatne szkolnictwo,

2. powszechne i obowiązkowe szkoły podstawowe,

3. upowszechnianie szkolnictwa średniego,

4. rozwój szkolnictwa wyższego,

5. pomoc państwa w podnoszeniu kwalifikacji obywateli zatrudnionych w zakładach przemysłowych i innych ośrodkach pracy w mieście i na wsi,

6. system stypendiów państwowych, rozbudowa burs, internatów i domów akademickich oraz innych form pomocy materialnej dla dzieci robotników, pracujących chłopów i inteligencji.

Aleksander S. — kandydat na studia (skarżący, strona) pismem z dnia 7 października 1981 roku, skierowanym do Naczelnego Sądu Administracyjnego (NSA), zaskarżył decyzję odmawiającą przyjęcia go na studia medyczne w Akademii Medycznej w W. Pismem z dnia 18 stycznia 1982 roku skarżący sprecyzował żądanie skargi w ten sposób, że

stroną przeciwną w tej sprawie jest Minister Zdrowia i Opieki Społecznej w Warszawie ul. Miodowa (Minister, Organ), przedmiotem zaskarżenia do Naczelnego Sądu Administracyjnego zaś jest niewydanie przez Ministra, jako organ nadzoru nad akademiami medycznymi w kraju,

26 Wyrok Naczelnego Sądu Administracyjnego w Warszawie z dnia 1 grudnia 2011 r., I OSK 1630/11 (CBOSA).

27 Ż. Semprich, op. cit. 
merytorycznej decyzji pisemnej o dopuszczeniu do studiów w uwzględnieniu mych odwołań do Ministra z dnia 14.VII., 10.VIII. i 11.IX.1981 r. od odmownych decyzji Rektora AM w W. ${ }^{28}$

Organ w odpowiedzi na skargę (datowanej 18 lutego 1982 roku, nr NO-074/ 1/82) i Rektor Akademii Medycznej w odpowiedzi nadesłanej do NSA w dniu 3 marca 1982 roku zakwestionowali dopuszczalność skargi sądowoadministracyjnej, twierdząc, że zakwalifikowanie na studia nie ma charakteru decyzji wydawanych $\mathrm{w}$ trybie ogólnego postępowania administracyjnego. Podnosili oni, że kwalifikowanie na studia odbywa się w odmiennym, szczególnym trybie, który regulują a) zarządzenie nr 11 Ministra Nauki, Szkolnictwa Wyższego i Techniki z dnia 24 maja 1980 roku w sprawie zasad i trybu przyjęć na I rok studiów dziennych w szkołach wyższych ${ }^{29}$, wydane na mocy upoważnienia zawartego w art. 37 ust. 5 ustawy $z$ dnia 5 listopada 1958 roku o szkolnictwie wyższym ${ }^{30}$ oraz wydane na podstawie $\S 8$ i 10 tego zarządzenia; b) wytyczne Ministra Zdrowia i Opieki Społecznej z dnia 21 maja 1981 roku w sprawie zasad i trybu kwalifikacji kandydatów na I rok studiów stacjonarnych w akademiach medycznych w 1981 roku (niepublikowane). W myśl tych przepisów postępowanie kwalifikacyjne przeprowadzają komisje wydziałowe oraz komisja uczelniana, do której należy wydanie ostatecznej decyzji w sprawie przyjęcia na studia. Pisma dotyczące nieprzyjęcia na studia Ministerstwo Zdrowia i Opieki Społecznej rozpatruje w trybie przewidzianym uchwałą nr 132 Rady Ministrów z dnia 28 listopada 1980 roku w sprawie organizacji przyjmowania, rozpatrywania i załatwiania skarg i wniosków ${ }^{31}$.

NSA, rozpoznając sprawę, stwierdził przede wszystkim, że nie może być uznany za uzasadniony pogląd organu, że zakwalifikowanie bądź odmowa zakwalifikowania na studia wyższe nie ma charakteru decyzji wydawanej w trybie ogólnego postępowania administracyjnego, gdyż odbywa się w odmiennym, szczególnym trybie, który reguluje wskazane zarządzenie Ministra Nauki, Szkolnictwa Wyższego i Techniki, wydane na podstawie upoważnienia zawartego w art. 37 ust. 5 ustawy o szkolnictwie wyższym.

Konstytucyjne prawo obywateli PRL do nauki w szkołach wyższych, jak podkreślał NSA, może być realizowane tylko na zasadach uregulowanych prawem administracyjnym. Oznacza to, że ta dziedzina życia społecznego została objęta reglamentacją administracyjną i studiować w szkole wyższej może tylko ten obywatel, który spełnia określone prawem warunki, a nadto zostanie do studiów dopuszczony przez właściwy organ szkoły wyższej. Szkoła wyższa jest

28 Wyrok Naczelnego Sądu Administracyjnego z dnia 29 czerwca 1982 r., II SA 532/82 (CBOSA).

29 Zarządzenie nr 11 Ministra Nauki, Szkolnictwa Wyższego i Techniki z dnia 24 maja 1980 r. w sprawie zasad i trybu przyjęć na I rok studiów dziennych w szkołach wyższych, Dz. Urz. MNSzWiT nr 4, poz. 13; zm. z 1981 nr 2, poz. 7.

30 Ustawa z dnia 5 listopada 1958 r. o szkolnictwie wyższym, Dz.U. $1973 \mathrm{Nr}$ 32, poz. 191.

31 Uchwała nr 132 Rady Ministrów z dnia 28 listopada 1980 r. w sprawie organizacji przyjmowania, rozpatrywania i załatwiania skarg i wniosków, M.P. nr 29, poz. 162. 
państwową jednostką organizacyjną należącą do kategorii zakładów użyteczności publicznej (zakładów administracyjnych) i ma przewidziane ustawą kompetencje, między innymi w zakresie doboru i kształcenia studentów.

Ze względu na ograniczone możliwości faktyczne szkoły wyższe nie są w stanie zaspokoić potrzeb wszystkich ubiegających się o dopuszczenie do studiów. Powstaje więc problem, także prawny, jak zagwarantować równość praw obywateli do zapewnienia świadczeń szkoły wyższej w postaci miejsca na studiach. Odpowiedzi w tej kwestii należy poszukiwać, analizując stosunek prawny łączący kandydata na studenta ze szkołą wyższą.

Następnie, przytaczając ustalenia doktryny prawa administracyjnego ${ }^{32}$, NSA wskazał, że stosunek prawny łączący studenta ze szkołą wyższą określany jest w nauce prawa jako tak zwany administracyjny stosunek zależności zakładowej. Stosunek ten nawiązuje się w wyniku postępowania kwalifikacyjnego, w którego toku sprawdza się, czy kandydat odpowiada warunkom przewidzianym w ustawie, ocenia się jego wiadomości $w$ dziedzinach objętych egzaminem, a także ustala przysługujące mu punkty preferencyjne z innych tytułów niż wynik egzaminu. Postępowanie kwalifikacyjne jest więc postępowaniem administracyjnym, w którego trakcie — spośród ubiegających się o przyjęcie na studia - ma zostać dokonany wybór tych, ,którzy w największym stopniu gwarantują pomyślne ukończenie nauki czy studiów"33. Wynik tego postępowania - przy uwzględnieniu liczby osób, które mogą być przyjęte na studia - przesądza o tym, czy ubiegający się o przyjęcie zostanie włączony w poczet studentów danej szkoły wyższej, a więc w poczet ,użytkowników zakładu”. Wydana przez właściwy organ szkoły wyższej decyzja o zakwalifikowaniu i przyjęciu bądź o nieprzyjęciu na I rok studiów należy więc do grupy aktów administracyjnych zewnętrznych, nazywanych niekiedy aktami administracyjnymi powszechnymi (wydawanymi $\mathrm{w}$ układzie prawa powszechnego ${ }^{34} \mathrm{w}$ odróżnieniu od wewnątrzzakładowych aktów administracyjnych, będących przejawem władztwa zakładowego i kształtujących stosunki prawne w ramach stosunku zakładowego. Wewnątrzzakładowe akty prawne nie stanowią jednak o nawiązaniu, przekształceniu lub rozwiązaniu tego stosunku, gdyż akt administracyjny w tym zakresie jest przejawem władztwa państwowego, a jego wydanie normują przepisy ogólnego postępowania administracyjnego ${ }^{35}$. Pod rządami k.p.a. z 1960 roku mogły istnieć wątpliwości, czy kodeks ten powinien być i w jakim zakresie stosowany w postępowaniu przed organami zakładów, toteż wysuwany był postulat „poszukiwań procesowego

32 J. Filipek, Stosunek administracyjnoprawny, Kraków 1968, s. 126.

33 E. Ochendowski, Organy administracji niezespolonej i zakłady administracyjne, [w:] System prawa administracyjnego, t. 2, Wrocław 1977, s. 362.

34 E. Ochendowski, Formy działania zakładu, [w:] Studia z zakresu prawa administracyjnego ku czci prof. dra Mariana Zimmermanna, Warszawa-Poznań 1973, s. 111.

35 Ustawa z dnia 14 czerwca 1960 r. - Kodeks postępowania administracyjnego, Dz.U. 1980 r. Nr 9, poz. 26 (dalej: kodeks postępowania administracyjnego, k.p.a.). 
uregulowania tego zagadnienia"36. Jednak, jak podkreśla NSA, już wtedy wypowiedziany został w piśmiennictwie pogląd, że ,dopuszczenie do korzystania z usług szkoły w charakterze użytkownika następuje w drodze indywidualnej decyzji administracyjnej (regulowanej co do trybu jej wydania i zaskarżenia przez przepisy kodeksu postępowania administracyjnego)"37.

Sąd zaznaczył jednocześnie, że po wejściu w życie ustawy z dnia 31 stycznia 1980 roku o Naczelnym Sądzie Administracyjnym oraz o zmianie ustawy - Kodeks postępowania administracyjnego art. 12 tej ustawy przeciął ewentualnie istniejące wątpliwości. Stanowi on bowiem, że z dniem wejścia w życie tej ustawy, $\mathrm{z}$ zastrzeżeniem ust. 2 i 3, tracą moc wszelkie przepisy dotyczące spraw unormowanych w k.p.a. Przepisy art. 12 ust. 2 i 3 ustawy nie utrzymują w mocy żadnych przepisów regulujących postępowanie w sprawie przyjęć kandydatów do szkół wyższych. Należy tu zauważyć, że przepis art. 37 ust. 5 ustawy z dnia 5 listopada 1958 roku o szkolnictwie wyższym stanowi, że Minister Nauki, Szkolnictwa Wyższego i Techniki określa szczegółowe warunki i tryb przyjęć na studia w szkole wyższej. Upoważnienie do określenia „szczegółowego trybu” przyjęć oznaczać może jedynie uprawnienie do uregulowania tych zagadnień, które tego wymagają ze względu na swoistość postępowania w sprawie przyjęć do szkół wyższych.

NSA stwierdził, że nie może więc być uznany za uzasadniony pogląd, że akt prawny rangi zarządzenia Ministra (wydany zresztą w formie zarządzenia opublikowanego jedynie w Dzienniku Urzędowym Ministerstwa) zmienił podstawowy tryb postępowania uregulowany w k.p.a. Z tego też względu należy przyjąć, że zarządzenie nr 11 Ministra Nauki, Szkolnictwa Wyższego i Techniki z dnia 24 maja 1980 roku w sprawie zasad i trybu przyjęć na I rok studiów dziennych w szkołach wyższych oraz wydane na podstawie $\S 8$ i 10 tego zarządzenia wytyczne Ministra Zdrowia i Opieki Społecznej z dnia 21 maja 1981 roku w sprawie zasad i trybu kwalifikacji kandydatów na I rok studiów stacjonarnych w akademiach medycznych w 1981 roku (niepublikowane), regulują — zgodnie z treścią przepisu upoważniającego - jedynie szczegółowy tryb postępowania kwalifikacyjnego, a więc sposób przeprowadzenia „postępowania wyjaśniającego”, mającego sprawdzić wiadomości kandydata wymagane na odpowiednim kierunku studiów, określają organy uprawnione do jego przeprowadzenia, a także do wydania decyzji w przedmiocie dopuszczenia do studiów. Natomiast zasady podstawowe postępowania administracyjnego, a zwłaszcza gwarancje procesowe przysługujące stronom, regulują przepisy k.p.a.

Sąd zaznaczył, iż nie ulega wątpliwości, że postępowanie kwalifikacyjne mające wyłonić tylko taką liczbę osób, jaka przewidziana jest w limitach przyjęć na I rok na poszczególne kierunki studiów w danym roku, ma niewątpliwie swoją specyfikę, toteż stosowanie takich instytucji k.p.a. jak wznowienie postępowania

36 E. Ochendowski, op. cit., s. 112.

37 J. Borkowski, Organizacja zarzadzania szkoła wyższa, Wrocław 1978, s. 95. 
lub stwierdzenie nieważności decyzji może być utrudnione. Jednakże podobna sytuacja występuje również w innych dziedzinach administracji państwowej, gdy organy administracji orzekają o przydziale takich dóbr deficytowych jak lokale mieszkalne bądź w drodze decyzji ustalają kandydatów na nabywców nieruchomości państwowych, gdy o dobra te ubiega się większa liczba kandydatów, niż istnieją możliwości ich zaspokojenia.

Przewidziana w omawianych wytycznych Ministra Zdrowia i Opieki Społecznej forma zakończenia postępowania kwalifikacyjnego przez wydanie „zaświadczeń" osobom, które nie zostały zakwalifikowane na I rok studiów ze względu na zbyt małą liczbę punktów bądź które nie zdały egzaminu wstępnego, jest konsekwencją poglądu, że postępowanie kwalifikacyjne na studia wyższe nie jest postępowaniem regulowanym przepisami k.p.a. NSA podkreśla, że obowiązująca w dniu wyrokowania ustawa z dnia 4 marca 1982 roku o szkolnictwie wyższym ${ }^{38}$ przewidywała w art. 89, że komisje rekrutacyjne podejmują decyzje w sprawie przyjęcia na studia. Tak więc ,nowa" ${ }^{39}$ ustawa o szkolnictwie wyższym wyjaśnia charakter rozstrzygnięcia w przedmiocie przyjęcia na studia wyższe, posługując się terminologią k.p.a.

Skoro więc rozstrzygnięcie w sprawie przyjęcia na I rok studiów wyższych, a więc rozstrzygnięcie w sprawie włączenia w poczet użytkowników zakładu administracyjnego, jakim jest szkoła wyższa, należy uznać za decyzję administracyjną wydaną w trybie określonym w k.p.a., to decyzja taka — stosownie do art. $196 \S 1$ i $~ 2$ pkt 14 k.p.a. — może być zaskarżona do sądu administracyjnego z powodu jej niezgodności z prawem. Ostatecznie w wyniku przeprowadzonego postępowania Naczelny Sąd Administracyjny uznał zasadność skargi strony na decyzję Ministra Zdrowia i Opieki Społecznej z dnia 4 września 1981 roku $\mathrm{nr}$ NW-528-A/x/31 w przedmiocie dopuszczenia do studiów w charakterze studenta i na podstawie art. $207 \S 2$ pkt 3 k.p.a. uchylił zaskarżoną decyzję.

\section{Wnioski końcowe}

Zasadniczo w okresie Polskiej Rzeczypospolitej Ludowej administracja publiczna nie podlegała w wymaganym zakresie kontroli sądowej mimo zgłaszanych postulatów zwłaszcza prawoznawstwa, w tym nauki prawa administracyjnego. W strukturze organizacyjnej państwa autorytarnego (komunistycznego), wznoszonego na wzorcach sowieckich, sądownictwo administracyjne było nie do przyjęcia z przyczyn „systemowych”. Podział władzy publicznej, system równoważenia i kontroli poszczególnych segmentów tej władzy oraz inne wyznaczniki państwa

38 Ustawa z dnia 4 marca 1982 r. o szkolnictwie wyższym, Dz.U. Nr 14 poz. 113.

$39 \mathrm{~W}$ stosunku do będącej podstawą wydania orzeczenia, to jest ustawa $\mathrm{z}$ dnia 5 listopada 1958 r. o szkolnictwie wyższym, Dz.U. 1973 Nr 32, poz. 191. 
prawa (demokratycznego państwa prawnego) zostały w tamtym czasie odrzucone na rzecz jedynowładztwa $\mathrm{z}$ przewodnią siłą polityczną społeczeństwa $\mathrm{w}$ budowie socjalizmu, którą była Polska Zjednoczona Partia Robotnicza. W omawianej formacji państwowej wolności i prawa jednostki z założenia musiały ustępować miejsca osiąganiu celów budownictwa socjalistycznego. Z oczywistych względów spory między aparatem wykonawczym PRL (administracją publiczną) a jednostkami rozstrzygane przez rzetelnie i sprawnie działające sądownictwo byłyby „utrudnieniem” w realizacji zadań państwa komunistycznego.

Przeprowadzone rozważania pozwalają stwierdzić, że reaktywacja sądownictwa administracyjnego w 1980 roku, powołanie jednoinstancyjnego i zarazem o ograniczonej kognicji Naczelnego Sądu Administracyjnego, rozpoczęła przede wszystkim proces przywracania właściwego miejsca wolnościom i prawom jednostki w państwie. Należy przypomnieć, że restytucja sądownictwa administracyjnego w warunkach PRL była poprzedzona przyjęciem w 1960 roku przywoływanego $\mathrm{w}$ opracowaniu kodeksu postępowania administracyjnego. Komisja ds. opracowania projektu k.p.a. stwierdzała, że określa on ,zasady działalności organów administracji państwowej występujących na zewnątrz w stosunku do obywateli, a zwłaszcza stosunek tych organów do obywatela przy orzekaniu o jego

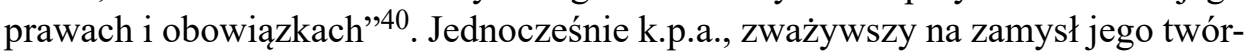
ców uwzględniający między innymi konieczność zapobiegania powszechnym nieprawidłowościom zachowań administracji publicznej PRL, spowodowanych brakiem sądownictwa administracyjnego tworzył w owym czasie najdalej idące rozwiązania proceduralne, chroniące jednostkę przed działaniami podmiotów wykonujących administrację publiczną w tamtym okresie ${ }^{41}$.

Mimo że Konstytucja PRL stwierdzała między innymi w art. 8 ust. 3, że: „Ścisłe przestrzeganie praw Polskiej Rzeczypospolitej Ludowej jest podstawowym obowiązkiem każdego organu państwa i każdego obywatela”, a art. 6 k.p.a. stanowił: „Organy administracji państwowej działają na podstawie przepisów prawa kierując się interesem ludu pracującego i zadaniami budownictwa socjalistycznego" - zbadana praktyka stosowania prawa administracyjnego z dziedziny szkolnictwa wyższego odnosząca się do kwestii przyjęć na studia ukazuje stan odmienny. Przedmiotowe orzeczenie NSA, niezależnie od prawidłowego rozpoznania skargi, ilustruje wiele istotnych, powiązanych z sobą procesów i zjawisk w obrębie rozwijania się kontroli sądowoadministracyjnej w schyłkowym okresie

40 Komisja do opracowania projektu przepisów o postępowaniu administracyjnym, Projekt Kodeksu postępowania administracyjnego. Uzasadnienie, Warszawa, kwiecień 1959 r., s. 50.

41 Por. J. Starościak, Na marginesie projektu kodeksu postępowania administracyjnego, „Państwo i Prawo" 1959, nr 4, s. 684; S. Rozmaryn, Projekt kodeksu postępowania administracyjnego w nowej postaci, „Państwo i Prawo” 1960, nr 4-5, s. 611; J. Jendrośka, Ewolucja ogólnego postepowania administracyjnego w Polsce, [w:] Studia z zakresu polityki finansowej i prawa finansowego, red. M. Mazurkiewicz, Wrocław 1992, s. 167. 
PRL. Zaakcentujmy niektóre z nich, odnośny wyrok przede wszystkim ukazuje, często spotykane $\mathrm{w}$ tamtym okresie, zachowanie administracji publicznej zmierzające do uniknięcia kontroli sądowoadministracyjnej przez zajęcia stanowiska, iż załatwienie sprawy administracyjnej — $\mathrm{w}$ analizowanym wypadku przyjęcie na studia oraz odmowa przyjęcia na studia — nie ma formy decyzji administracyjnej. Forma decyzji administracyjnej zapewniała niniejszym realizowanie przedmiotowej kontroli przez NSA, który w swoim orzecznictwie zawsze dążył do objęcia kognicją wszystkich wymaganych działań władzy wykonawczej. Ustalenie w orzeczeniu, że zakwalifikowanie bądź odmowa zakwalifikowania na studia wyższe ma postać decyzji wydawanej w trybie k.p.a., dało w dalszej kolejności podstawę do weryfikacji zaskarżonej decyzji odmawiającej przyjęcia na studia medyczne w Akademii Medycznej w W. z punktu widzenia wymogów ogólnego postępowania administracyjnego. Ocena zaskarżonego działania administracji publicznej w świetle k.p.a. była kluczowa do wyniku zrealizowanej kontroli (uchylenia zaskarżonej decyzji). Analizowany judykat ilustruje także wielopoziomowy („rozchwiany”) system źródeł prawa, znamienny dla okresu PRL, który kształtował załatwienie sprawy administracyjnej jednostki: ustawa o szkolnictwie wyższym, zarządzenie Ministra Nauki, Szkolnictwa Wyższego i Techniki czy niepublikowane wytyczne Ministra Zdrowia i Opieki Społecznej z dnia 21 maja 1981 roku w sprawie zasad i trybu kwalifikacji kandydatów na I rok studiów stacjonarnych w akademiach medycznych w 1981 roku. Zjawisko to potwierdza znaczną wagę prawotwórstwa administracyjnego (legislacji administracyjnej), $\mathrm{w}$ tym nieznajdującego bezpośredniego umocowania $\mathrm{w}$ prawie pochodzenia parlamentarnego, dla budowania systemu prawa administracyjnego w PRL. Na uwypuklenie zasługuje także zwerbalizowanie w zbadanym wyroku odwołanie się przez NSA do postanowień ustawy zasadniczej kształtującej konstytucyjne prawo obywateli PRL do nauki w szkołach wyższych. Na gruncie dzisiejszej praktyki i nauki byłby to wyraz przyjaznej konstytucji wykładni przepisów prawa administracyjnego z zakresu szkolnictwa wyższego. Ponadto należy uwypuklić, że NSA na gruncie analizowanego orzeczenia wielokrotnie przywoływał właściwe poglądy prawoznawstwa jako dodatkowe wsparcie swojej argumentacji. Nauka prawa administracyjnego uprawiana $\mathrm{w}$ okresie państwa autorytarnego, ale nie tylko ten odcinek prawoznawstwa, formułowała wnioski naukowe, które okazywały się wartościowe dla sprawowania rzetelnej i sprawnej kontroli nad działalnością administracji publicznej w dziedzinie szkolnictwa wyższego w PRL. Ostatecznie należy stwierdzić, że rozszerzana i pogłębiana sądowoadministracyjna kontrola przyjęć na studia pozytywnie wpływała na faktyczną realizacje praw i wolności jednostki o obszarze szkolnictwa wyższego w minionej formacji państwowej. Orzecznictwo utworzonego w roku 1980 Naczelnego Sądu Administracyjnego przypomnijmy za M. Kuleszą — otwierając nowe perspektywy w badaniach nad 
prawem administracyjnym, stworzyło jednocześnie przesłanki do zmiany dotychczasowych metod nauczania prawa administracyjnego 42 .

\section{Bibliografia}

Adamiak B., Instytucje prawne równowagi władzy wykonawczej $i$ władzy sądowniczej w procesowym prawie administracyjnym i sądowoadministracyjnym, [w:] W kręu doktryn politycznych i prawnych. Ksiega jubileuszowa dedykowana Profesorowi Markowi Maciejewskiemu, red. R. Antonów, Ł. Machaj, M. Marszał, M. Sadowski, T. Scheffler, Wrocław 2020.

Arendt H., Korzenie totalitaryzmu, t. 1, przeł. D. Grinberg, M. Szawiel, Warszawa 1989.

Bäcker R., Rak J., Polski autorytaryzm 2015-2019, [w:] W kręgu doktryn politycznych i prawnych. Księga jubileuszowa dedykowana Profesorowi Markowi Maciejewskiemu, red. R. Antonow, Ł. Machaj, M. Marszał, M. Sadowski, T. Scheffler, Wrocław 2020.

Bigo T., Prawo administracyjne, cz. 1. Instytucje ogólne, Wrocław 1948.

Bigo T., Trzy sugestie w sprawie sądownictwa administracyjnego, „Zeszyty Naukowe Uniwersytetu Wrocławskiego” 1958, Seria A, nr 10, „Prawo” 3.

Boć J., Konstytucja a prawo administracyjne, „Ruch Prawniczy, Ekonomiczny i Socjologiczny” 2011, z. 2.

Borkowski J., Organizacja zarządzania szkoła wyższa, Wrocław 1978.

Buzek J., Studya z zakresu administracyi wychowania publicznego, I. Szkolnictwo ludowe, Lwów 1904.

Ciechocki J., Komentarz, „Organizacja Metody Techniki” 1984, nr 3.

Filipek J., Glosa, „Państwo i Prawo” 1983, nr 8.

Filipek J., Stosunek administracyjnoprawny, Kraków 1968.

Gati Ch., Wprowadzenie, [w:] Zbigniew Brzeziński. Strateg i mąż stanu, red. Ch. Gati, Warszawa 2014.

Homplewicz J., Glosa, Orzecznictwo Sądów Polskich i Komisji Arbitrażowych 1983, z. 1, poz. 20. Jaroszyński M., Zimmermann M., Brzeziński W., Polskie prawo administracyjne, Warszawa 1956. Jendrośka J., Ewolucja ogólnego postępowania administracyjnego w Polsce, [w:] Studia z zakresu polityki finansowej i prawa finansowego, red. M. Mazurkiewicz, Wrocław 1992.

Kennan G.F., Totalitaryzm w świecie współczesnym, [w:] Totalitaryzm. Materiały z konferencji zorganizowanej przez Amerykańska Akademię Sztuk i Nauk w marcu 1953 roku, red. C.J. Friedrich, przeł. S. Szymański, Warszawa 2019.

Kulesza M., Uwagi wstępne, [w:] Z orzecznictwa sadowego. Materiały do nauki prawa administracyjnego, red. M. Kulesza, Warszawa 1985.

Kumaniecki K.W., Langrod J.S., Wacholz S., Zarys ustroju, postępowania i prawa administracyjnego w Polsce, Kraków 1939.

Langrod J.S., Kontrola administracji. Studja, Warszawa 1929.

Litwin J., Problematyka sądownictwa administracyjnego. Zagadnienia organizacji i procedury, „Nowe Prawo” 1956, z. 10.

Longchamps F., Założenia nauki administracji, Wrocław 1949.

Ochendowski E., Formy działania zakładu, [w:] Studia z zakresu prawa administracyjnego ku czci prof. dra Mariana Zimmermanna, Warszawa-Poznań 1973.

${ }^{42}$ M. Kulesza, Uwagi wstepne, [w:] Z orzecznictwa sądowego. Materialy do nauki prawa administracyjnego, red. M. Kulesza, Warszawa 1985, s. 7. 
Ochendowski E., Organy administracji niezespolonej i zakłady administracyjne, [w:] System prawa administracyjnego, t. 2, Wrocław 1977.

Rozmaryn S., Projekt kodeksu postępowania administracyjnego - w nowej postaci, „Państwo i Prawo" $1960, \mathrm{nr} 4-5$.

Sartori G., Teoria demokracji, przeł. P. Amsterdamski, D. Grinberg, Warszawa 1994.

Semprich Ż., Spór o indeks, „Rzeczpospolita” 24.08.1983.

Starościak J., Na marginesie projektu kodeksu postępowania administracyjnego, „Państwo i Prawo” 1959, $\mathrm{nr} 4$.

Świątkiewicz J., Sądowa kontrola działalności administracji w PRL, „Państwo i Prawo” 1976, nr 8-9.

Trzciński J., Sadownictwo administracyjne jako gwarant ochrony wolności i praw jednostki, [w:] Trzecia władza. Sąy i trybunaty w Polsce. Materiały z L Ogólnopolskiego Zjazdu Katedr i Zakładów Prawa Konstytucyjnego, Gdynia 24-26 kwietnia 2008 roku, red. A. Szmyt, Gdańsk 2008.

Twardowski K., O dostojeństwie Uniwersytetu, Poznań 2011 (reprint wyd. z 1933 r.).

Wyrzykowski M., Sądownictwo administracyjne w Polskiej Rzeczpospolitej Ludowej, Warszawa 1983.

Zimmermann M., Nauka administracji i polskie prawo administracyjne. Część I, Poznań 1949.

Znamierowski C., Elita, ustrój, demokracja. Pisma wybrane, Warszawa 2001.

\section{Akty normatywne i inne}

Konstytucja Polskiej Rzeczypospolitej Ludowej uchwalona przez Sejm Ustawodawczy w dniu 22 lipca 1952 r., tekst jedn. Dz.U. 1976 r. Nr 7, poz. 36.

Ustawa z dnia 29 grudnia 1989 r. o zmianie Konstytucji Polskiej Rzeczypospolitej Ludowej, Dz.U. $\mathrm{Nr} 75$, poz. 444.

Konstytucja Rzeczypospolitej Polskiej z dnia 2 kwietnia 1997 r., Dz.U. 78, poz. 483, sprost. Dz.U. z 2001 r. Nr 28, poz. 319 z późn. zm.

Ustawa z dnia 5 listopada 1958 r. o szkolnictwie wyższym, Dz.U. 1973 Nr 32, poz. 191.

Ustawa z dnia 14 czerwca 1960 r. — Kodeks postępowania administracyjnego, Dz.U. 1980 r. Nr 9, poz. 26.

Ustawa z dnia 31 stycznia 1980 r. o Naczelnym Sądzie Administracyjnym oraz o zmianie ustawy Kodeks postępowania administracyjnego, Dz.U. Nr 4, poz. 8.

Ustawa z dnia 4 marca 1982 r. o szkolnictwie wyższym, Dz.U. Nr 14 poz. 113.

Ustawa z dnia 27 lipca 2005 r. - Prawo o szkolnictwie wyższym, Dz.U. z 2012 r. poz. 57 z późn. zm.

Ustawa z dnia 20 lipca 2018 r. — Prawo o szkolnictwie wyższym i nauce, Dz.U. z 2020 r. poz. 85 z późn. $z m$.

Zarządzenie nr 11 Ministra Nauki, Szkolnictwa Wyższego i Techniki z dnia 24 maja 1980 r. w sprawie zasad i trybu przyjęć na I rok studiów dziennych w szkołach wyższych, Dz. Urz. MNSzWiT nr 4 poz. 13; zm.: z $1981 \mathrm{nr}$ 2, poz. 7.

Uchwała nr 132 Rady Ministrów z dnia 28 listopada 1980 r. w sprawie organizacji przyjmowania, rozpatrywania i załatwiania skarg i wniosków, M.P. nr 29 poz. 162.

Wytyczne Ministra Zdrowia i Opieki Społecznej z dnia 21 maja 1981 r. w sprawie zasad i trybu kwalifikacji kandydatów na I rok studiów stacjonarnych w akademiach medycznych w $1981 \mathrm{r}$. (niepubl.).

Pismo Ministerstwa Szkół Wyższych i Nauki z dnia 26 stycznia 1951 r. Nr DN-55/pfu/50.r. POUFNE. Komisja do opracowania projektu przepisów o postępowaniu administracyjnym, Projekt Kodeksu postępowania administracyjnego. Uzasadnienie, Warszawa, kwiecień $1959 \mathrm{r}$. 


\section{Orzecznictwo}

Wyrok Naczelnego Sądu Administracyjnego z dnia 29 czerwca 1982 r., II SA 532/82 (CBOSA).

Wyrok Naczelnego Sądu Administracyjnego w Warszawie z dnia 1 grudnia 2011 r., I OSK 1630/11 (CBOSA).

Wyrok Trybunału Konstytucyjnego z dnia 9 marca 2016 r., K 47/15, Orzecznictwo Trybunału Konstytucyjnego. Zbiór Urzędowy 2016. Seria A, poz. 2, s. 85. 